\title{
PENINGKATAN KEMAMPUAN MENCERITAKAN KEMBALI CERITA PENDEK (CERPEN) MATA PELAJARAN BAHASA INDONESIA DENGAN METODE DISKUSI PADA SISWA KELAS IX.4 SMPN 21 PEKANBARU
}

\author{
Jun Irma \\ SMP Negeri 21 Pekanbaru \\ e-mail: junirmasmp21@yahoo.com
}

\begin{abstract}
Activities This devotion is downstream of research that is motivated by the low ability to retell short stories in Indonesian language lessons students of class IX.4 SMP Negeri 21 Pekanbaru. This study aims to improve the ability to retell short stories in Indonesian lessons with the method of discussion on the students of class IX.9 SMP Negeri 21 Pekanbaru. The subjects of this study were all students of class IX.9 SMPN 21 Pekanbaru which amounted to 40 people, the academic year 20162017. The form of research is classroom action research. The instrument of this research consisted of performance instrument and data collection instrument in the form of observation sheet of teacher activity and student activity. Based on the results of the research, the conclusion of this study is to improve the ability to retell short stories (short stories) with the method of discussion of students Class IX.4 SMPN 21 Pekanbaru. The average of students on the initial test is categorized as being with an average score of 71.50 , with a percentage of completeness $40 \%$ or there are 16 students who are declared complete and the remaining 24 students declared unfinished with a percentage of $60 \%$, In cycle I, student grade rose to 78,13 with moderate category, with $65 \%$ complete percentage value or with number of 26 student, In cycle II average ability of student have been categorized high with mean value 88,13 , but with mastery $85 \%$, where the students' mastery score has been met. The above statement shows that the ability to retell the short story (short story) with the discussion method of students of Class IX.4 SMPN 21 Pekanbaru can be improved through discussion method, thus the research hypothesis which reads: "Improvement Capability of Retelling Short Story (Short story) with Discussion Method Students of Class IX.4 SMPN 21 Pekanbaru can be "accepted"
\end{abstract}

Keywords: Ability to Retell the Short story, Method of Discussion

\begin{abstract}
Abstrak
Kegiatan Pengabdian ini merupakan hilirisasi dari penelitian yang dilatarbelakangi oleh rendahnya kemampuan menceritakan kembali cerpen pada pelajaran bahasa Indonesia siswa kelas IX.4 SMP Negeri 21 Pekanbaru. Penelitian ini bertujuan untuk meningkatkan kemampuan menceritakan kembali cerpen pada pelajaran bahasa Indonesia dengan metode diskusi pada siswa kelas IX.9 SMP Negeri 21 Pekanbaru. Subjek penelitian ini adalah semua siswa kelas IX.9 SMPN 21 Pekanbaru yang berjumlah 40 orang, tahun pelajaran 2016-2017. Bentuk penelitian adalah penelitian tindakan kelas. Instrumen penelitian ini terdiri dari instrumen unjuk kerja dan instrumen pengumpulan data berupa lembar observasi aktivitas guru dan aktivitas siswa. Berdasarkan hasil penelitian, maka diperoleh kesimpulan terhadap penelitian ini adalah untuk meningkatkan kemampuan menceritakan kembali cerita pendek (cerpen) dengan metode diskusi terhadap siswa Kelas IX.4 SMPN 21 Pekanbaru. Rata-rata siswa pada tes awal dikategorikan sedang dengan nilai rata-rata 71,50, dengan nilai persentase ketuntasan $40 \%$ atau ada 16 siswa yang dinyatakan tuntas dan sisanya 24 siswa dinyatakan tidak tuntas dengan persentase 60\%, Pada siklus I, nilai kemampuan rata-rata siswa naik menjadi 78,13 dengan kategori sedang, dengan nilai persentase ketuntasan 65\% atau dengan jumlah 26 orang siswa, Pada siklus II kemampuan rata-rata siswa telah dikategorikan tinggi dengan nilai rata-rata 88,13, tetapi dengan ketuntasan 85\%, dimana nilai ketuntasan siswa telah tercapi. Pernyataan di atas menunjukkan bahwa kemampuan menceritakan kembali cerita pendek (cerpen) dengan metode diskusi siswa Kelas IX.4 SMPN 21 Pekanbaru dapat ditingkatkan melalui metode diskusi, dengan demikian hipotesis penelitian yang berbunyi: "Peningkatan
\end{abstract}


Kemampuan menceritakan kembali Cerita Pendek (Cerpen) dengan Metode diskusi Siswa Kelas IX.4 SMPN 21 Pekanbaru dapat "diterima".

Kata kunci: Kemampuan Menceritakan Kembali Cerpen, Metode Diskusi

\section{PENDAHULUAN}

Dalam suatu pembelajaran, pendekatan memang bukan segala-galanya. Masih banyak faktor lain yang ikut menentukan keberhasilan suatu pembelajaran. Faktor-faktor tersebut antara lain kurikulum, program pengaajaran, kualitas guru, materi pembelajaran, strategi pembelajaran, sumber belajar dan tehnik/bentuk penilaian. Ini berarti pendekatan hanyalah salah satu faktor dari sekian banyak faktor yang perlu mendapatkan perhatian dalam keseluruhan pengelolaan pembelajaran.

Siswa atau anak didik adalah salah satu komponen manusiawi yang menempati posisi sentral dalam proses belajar mengajar. Di dalam proses belajar mengajar, siswa sebagai pihak yang ingin meraih cita-cita, memiliki tujuan dan kemudian ingin mencapainya secara optimal. Siswa atau anak didik itu akan menjadi faktor penentu, sehingga menuntut dan dapat mempengaruhi segala sesuatu yang diperlukan untuk mencapai tujuan belajarnya.

Sehubungan dengan hal tersebut, rendahnya hasil belajar dipengaruhi oleh cara penyajian atau metode mengajar guru. Kondisi ini senada dengan pernyataan Muhibbin Syah (1995;132), secara global, faktor-faktor yang mempengaruhi belajar seseorang dapat dibedakan menjadi tiga macam yaitu faktor internal (faktor dari dalam diri siswa) yakni keadan/kondisi jasmani dan rohani siswa, faktor eksternal (faktor dari luar siswa)yakni kondisi lingkungan di sekitar siswa dan faktor pendekatan belajar (approach to learning) yakni jenis upaya belajar siswa yang meliputi strategi dan metode yang digunakan untuk melakukan kegiatan pembelajaran materi-materi pelajaran.

Pembelajaran bahasa Indonesia di sekolah diarahkan untuk meningkatkan kemampuan siswa dalam berkomunikasi dengan bahasa Indonesia baik secara lisan maupun tulisan. Untuk mewujudkannya maka pelajaran bahasa Indonesia diprogramkan untuk mengembangkan pengetahuan, sikap positif terhadap bahasa Indonesia dan ketrampilan berbahasa. Adapun ketrampilan berbahasa dalam kurikulum terdiri atas empat aspek, yaitu ketrampilan menyimak, ketrampilan berbicara, ketrampilan membaca dan ketrampilan menulis.

Berbicara adalah suatu ketrampilan berbahasa yang berkembang pada kehidupan anak, yang hanya didahului oleh keterampilan menyimak, dan pada masa tersebutlah kemampuan berbicara atau berujar dipelajari. Berbicara sudah barang tentu erat berhubungan dengan perkembangan kosa kata yang diperoleh oleh sang anak melalui kegiatan menyimak dan membaca. Kebelum matangan dalam perkembangan bahasa juga merupakan suatu keterlambatan dalam kegiatan-kegiatan berbahasa. Juga perl disadari bahwa ketrampilan-ketrampilan yang diperlukan bagi kegiatan berbicara yang efektif banyak persamaannya dengan yang dibutuhkan bagi komunikasi efektif dalam ketrampilanketrampilan berbahasa lainnya.

Berdasarkan hasil pengamatan selama peneliti bertugas di SMPN 21 Pekanbaru ditemui gejalagejala atau fenomena khususnya pada aspek kemampuan menceritakan cerpen yaitu, sebagai berikut: 1) Rendahnya kemampuan siswa dalam bercerita. Pada tes awal (hanya 70,91\%) dari 40 orang siswa hanya 12 orang yang dapat bercerita dengan baik, sedangkan sisanya belum dapat bercerita dengan baik, 2) Kurangnya pemahaman siswa dalam memahami aspek-aspek yang terkandung dalam suatu cerita, 3) Siswa kesulitan dalam menentukan unur-unsur cerita dalam cerpen dan kurang kinginannya untuk bertanya pada guru.

Oleh sebab itu peneliti tertarik ingin melakukan suatu penelitian tindakan sebagai upaya dalam melakukan perbaikan terhadap hasil pembelajaran dengan judul "Peningkatan Kemampuan Menceritakan Kembali Cerita Pendek (cerpen) Mata Pelajaran Bahasa Indonesia Dengan Metode Diskusi Pada Siswa Kelas IX.4 SMPN 21 Pekanbaru" 


\section{METODE}

Penelitian dilaksanakan di SMPN 21 Pekanbaru pada Kelas IX.4 pada tahun 2016. Penelitian ini telah dilaksanakan pada September 2016 sampai Oktober 2016. Penelitian ini dilakukan dalam 2 siklus.

Subjek dalam penelitian ini adalah siswa Kelas IX.4 SMPN 21 Pekanbaru tahun pelajaran 2016/2017 dengan jumlah siswa sebanyak 40 orang. Jenis penelitian ini adalah Penelitian Tindakan Kelas (PTK). Penelitian Tindakan Kelas (PTK) merupakan salah satu langkah dalam mengembangkan keterampilan dan meningkatkan kinerja guru agar keberhasilan proses belajar mengajar dalam pencapaian hasil belajar dapat di peroleh semaksimal mungkin

\section{HASIL DAN PEMBAHASAN}

\subsection{Hasil}

\subsubsection{Siklus I}

Mengacu pada hasil yang diperoleh pada pelaksanaan tindakan siklus I ini, maka refleksi dilakukan dengan menganalisa setiap tahapan. Hasil analisis tersebut akan dipergunakan sebagai acuan dan tindak lanjut untuk siklus berikutnya. Refleksi siklus I adalah sebagai berikut:

1) Pada tahap perencanaan, guru telah melakukan persiapan pembelajaran dengan matang. Kegiatan pembelajaran telah tergambar jelas pada RPP yang telah dipersiapkan sebelumnya. Dengan demikian, pada siklus berikutnya guru tidak akan melakukan perubahan pada RPP. Perubahan yang dilakukan hanya pada instrumen tes. Jika pada siklus I siswa diberikan cerita dengan judul "Melihat sirkus", pada siklus berikutnya guru akan memberikan cerita yang berjudul "Layanglayangku". Hal ini perlu dilakukan agar siswa terbiasa mengahadapi berbagai bentuk cerita yang berbeda dalam kemampuan menceritakan cerpen yang disimak.

2) Pada kegiatan inti pelaksanaan tindakan untuk siklus II, guru akan menjelaskan lebih rinci lagi mengenai materi ajar. Tujuannya agar siswa memiliki konsep dasar dan pemahaman yang semakin kokoh tentang materi yang dipelajarinya, sehingga ketika dilaksankan tes, siswa mampu melaksanakan tugas yang diberikan guru dengan baik.

3) Observasi aktivitas guru pada siklus I masih terdapat 4 aktivitas yang memperoleh nilai cukup. Dan dengan rata-rata penilain dengan kategori cukup pula. Observasi aktivitas siswa yang diperoleh bervariasi, ada siswa yang aktif melakukan 9 aktivitas, dan ada siswa yang hanya melakukan 8 aktivitas. Namun, rata-rata aktivitas siswa secara klasikal memperoleh persentase nilai dengan nilai rata $72,5 \%$ dengan kategori nilai tinggi.

Hasil evaluasi pada siklus I diperoleh bahwa rata-rata kemampuan menceritakan kembali cerpen dengan metode diskusi siswa Kelas IX.4 SMPN 21 Pekanbaru adalah 78,13 dengan kategori tinggi, hal ini berarti rata-rata kemampuan menceritakan kembali cerpen dengan metode diskusi masih tergolong tinggi namun belum mencapai ketuntasan kelas secara klasikal. Ditinjau dari segi ketuntasan klasikal atau ketuntasan individu dari 40 siswa hanya 26 siswa atau $65 \%$ yang mencapai ketuntasan atau mendapatkan nilai diatas 78 . sedangkan 14 siswa lainnya atau 35\% masih mendapatkan nilai dibawah 78. karena jumlah ketuntasan klasikal belum mencapai $78 \%$ maka perlu diadakan perbaikan pada siklus berikutnya

\subsubsection{Siklus II}

Berdasarkan pelaksanaan tindakan pada siklus II, diperoleh hasil refleksi sebagai berikut:

1. Observasi aktivitas guru pada siklus II telah terlaksana dengan baik. Hal tersebut terbukti dari rata-rata skor yang diperoleh guru pada siklus II ini adalah 4,33. Ada 5 aspek aktivitas guru yang memperoleh skor 5 atau dengan kategori nilai baik sekali, yaitu pada aspek: memberikan apersepsi kepada siswa, menceritakan sebuah cerita pada siswa, meminta siswa menuliskan kembali cerita itu, dan memberikan kesimpulan

2. Observasi aktivitas yang diperoleh siswa pada siklus II mengalami peningkatan. Pada siklus I rata-rata aktivitas siswa secara klasikal memperoleh persentase nilai dengan nilai rata $72,5 \%$ dengan kategori nilai tinggi, meningkat menjadi 86,9\% dengan kategori nilai tinggi. 
3. Hasil evaluasi pada siklus II diperoleh bahwa rata-rata kemampuan menentukan unsur cerita dengan metode diskusi siswa Kelas IX.4 SMPN 21 Pekanbaru pada siklus I adalah 78,13, meningkat menjadi 83,13 dengan kategori nilai tinggi. Hal ini berarti rata-rata kemampuan smenceritakan kembali cerpen dengan metode diskusi telah mencapai nilai ketuntasan yang ditetapkan (minimal 78).

Ditinjau dari segi ketuntasan klasikal atau ketuntasan individu dari 40 siswa terdapat 34 (85\%) siswa dinyatakan mencapai ketuntasan atau mendapatkan nilai di atas 78. Sedangkan 6 siswa yang mendapatkan nilai dibawah 78. karena jumlah ketuntasan klasikal telah mencapai $85 \%$ maka, peneliti tidak perlu mengadakan perbaikan lagi pada siklus berikutnya

\subsection{Pembahasan}

\subsubsection{Aktivitas Guru}

Data dari aktivitas guru terlihat pada lembaran observasi di atas, guru atau peneliti telah melaksanakan pembelajaran dengan baik. Peneliti mengajar dengan perangkat pembelajaran lengkap yakni silabus dan RPP, menguasai materi pelajaran, melakukan pengelolaan kelas dengan baik. Pada siklus I ada 2 kategori aktivitas guru yang masih memperoleh nilai dengan kategori nilai cukup.

Siklus 1 menunjukkan bahwa secara klasikal rata-rata skor aktivitas guru pada siklus I adalah 3,67 dengan kategori penilaian cukup. Pada siklus berikutnya, peneliti akan mengadakan perbaikan, dan akan lebih optimal lagi dalam menjalankan aktivitas dalam proses pembelajaran

Observasi guru untuk siklus II, bahwa nilai rata-rata skor aktivitas guru meningkat dari 3,67 menjadi 4,44 dengan kategori baik. Dari 9 aktivitas yang diamati, terdapat 4 aktivitas guru yang memperoleh nilai dengan kategori penilaian baik sekali.

Proses pembelajaran telah dilaksanakan dengan baik oleh guru. Dengan peningkatan aktivitas guru membawa pengaruh yang positif terhadap aktivitas siwa dalam proses pebelajaran.

Tabel 1. Perbandingan Aktivitas Guru Siklus I dan II

\begin{tabular}{|c|c|c|c|c|}
\hline \multirow[t]{2}{*}{ No } & \multirow[t]{2}{*}{ Aktivitas } & \multicolumn{2}{|c|}{ Skor } & \multirow[t]{2}{*}{ Keterangan } \\
\hline & & Siklus I & Siklus II & \\
\hline 1 & $\begin{array}{l}\text { Merumuskan tujuan dan masalah yang akan } \\
\text { dijadikan topik diskusi. }\end{array}$ & 4 & 5 & Meningkat \\
\hline 2 & $\begin{array}{l}\text { Menyiapkan sarana dan prasarana yang } \\
\text { diperlukan untuk diskusi }\end{array}$ & 4 & 5 & Meningkat \\
\hline 3 & Menyusun peranan peerta didik dalam diskusi & 3 & 4 & Meningkat \\
\hline 4 & $\begin{array}{l}\text { Memberikan penghargaan kepada yang aktif } \\
\text { dalam kegiatan diskusi. }\end{array}$ & 4 & 4 & Tetap \\
\hline 5 & $\begin{array}{l}\text { Menciptakan suasana kondusif sehingga siswa } \\
\text { dapat mengemukakan pendapat }\end{array}$ & 3 & 4 & Meningkat \\
\hline 6 & $\begin{array}{l}\text { Memberikan kesempatan kepada siswa secara } \\
\text { merata. }\end{array}$ & 4 & 5 & Meningkat \\
\hline 7 & $\begin{array}{l}\text { Menyesuaikan penyelenggaraan diskusi } \\
\text { dengan waktu yang tersedia. }\end{array}$ & 4 & 4 & Tetap \\
\hline 8 & Memimpin diskusi agar diskusi bejalan lancar. & 4 & 5 & Meningkat \\
\hline 9 & Merumuskan kesimpulan dari diskusi & 3 & 4 & Meningkat \\
\hline & Jumlah skor & 33 & 40 & \\
\hline & Rata-rata Skor & 3.67 & 4.44 & Meningkat \\
\hline
\end{tabular}

\subsubsection{Aktivitas Siswa}

Rata-rata persentase aktivitas siswa pada siklus I adalah 72,5\% dengan kategori tinggi

Aktivitas siswa dalam proses pembelajaran dapat diamati dengan menggunakan lembar observasi pada setiap pertemuan.

Rata-rata persentase aktivitas siswa pada siklus II adalah 86,9 dengan kategori tinggi. Berikut rincian aktivitas siswa pada siklus II: 
a. Mendengarkan penjelasan guru tentang tujuan disikusi, diperoleh persentase $97.5 \%$ dengan kategori tinggi

b. Bersama guru menyiapkan sarana dan prasarana yang diperlukan, diperoleh persentase $87,5 \%$ dengan kategori tinggi

c. Melaksanakan peran dalam diskusi dengan baik, diperoleh persentase $87,5 \%$ dengan kategori tinggi

d. Semangat untuk memperoleh penghargaan dari guru, diperoleh persentase $82,5 \%$ dengan kategori tinggi

e. Dapat mengemukakan pendapat, diperoleh persentase $82,5 \%$ dengan kategori tinggi

f. Secara bergantian mengajukan pendapat atau pertanyaan, diperoleh persentase $92,5 \%$ dengan kategori tinggi

g. Menggunakan waktu dengan sebaik-baiknya, diperoleh persentase $82,5 \%$ dengan kategori tinggi

h. Mengikuti diskusi dengan baik dan semangat, diperoleh persentase $90 \%$ dengan kategori tinggi

i. Membuat kesimpulan terhadap hasil diskusi, diperoleh persentase $80 \%$ dengan kategori tinggi

Tabel 2. Perbandingan Aktivitas Siswa Siklus I dan II

\begin{tabular}{|c|c|c|c|c|c|c|}
\hline \multirow{2}{*}{ No } & \multirow{2}{*}{ Aktivitas yang Diamati } & \multicolumn{2}{|c|}{ Siklus I } & \multicolumn{2}{|c|}{ Siklus II } & \multirow{2}{*}{ Rata-Rata } \\
\hline & & Skor & $\%$ & Skor & $\%$ & \\
\hline 1 & $\begin{array}{l}\text { Mendengarkan penjelasan guru tentang } \\
\text { tujuan disikusi }\end{array}$ & 25 & $62.5 \%$ & 39 & $97.5 \%$ & $80.0 \%$ \\
\hline 2 & $\begin{array}{l}\text { Bersama guru menyiapkan sarana dan } \\
\text { prasarana yang diperlukan }\end{array}$ & 31 & $77.5 \%$ & 35 & $87.5 \%$ & $82.5 \%$ \\
\hline 3 & $\begin{array}{l}\text { Melaksanakan peran dalam diskusi } \\
\text { dengan baik }\end{array}$ & 31 & $77.5 \%$ & 35 & $87.5 \%$ & $82.5 \%$ \\
\hline 4 & $\begin{array}{l}\text { Semangat untuk memperoleh } \\
\text { penghargaan dari guru }\end{array}$ & 26 & $65.0 \%$ & 33 & $82.5 \%$ & $73.8 \%$ \\
\hline 5 & Dapat mengemukakan pendapat & 29 & $72.5 \%$ & 33 & $82.5 \%$ & $77.5 \%$ \\
\hline 6 & $\begin{array}{l}\text { Secara bergantian mengajukan pendapat } \\
\text { atau pertanyaan }\end{array}$ & 32 & $80.0 \%$ & 37 & $92.5 \%$ & $86.3 \%$ \\
\hline 7 & $\begin{array}{l}\text { Menggunakan waktu dengan sebaik- } \\
\text { baiknya }\end{array}$ & 33 & $82.5 \%$ & 33 & $82.5 \%$ & $82.5 \%$ \\
\hline 8 & $\begin{array}{l}\text { Mengikuti diskusi dengan baik dan } \\
\text { semangat }\end{array}$ & 30 & $75.0 \%$ & 36 & $90.0 \%$ & $82.5 \%$ \\
\hline 9 & $\begin{array}{l}\text { Membuat kesimpulan terhadap hasil } \\
\text { diskusi }\end{array}$ & 24 & $60.0 \%$ & 32 & $80.0 \%$ & $70.0 \%$ \\
\hline \multicolumn{2}{|c|}{ Jumlah skor } & & $652.5 \%$ & & $782.5 \%$ & $1435.0 \%$ \\
\hline \multicolumn{2}{|c|}{ Rata-rata } & & $72.5 \%$ & & $86.9 \%$ & $79.7 \%$ \\
\hline
\end{tabular}

\subsubsection{Hasil Evaluasi Kemampuan} tinggi.

Kemampuan siswa dalam menceritakan kembali cerita pendek adalah 78,13 dengan kategori

nilai rata-rata kemampuan siswa dalam menentukan unsur cerita adalah 83,13 dengan kategori tinggi. Berikut rincian dari data kemampuan belajar siswa :

a. Kemampuan siswa dalam menceritakan kembali cerpen pada indikator pemyampaian alur cerita diperoleh nilai rata-rata 31,50 dari nilai maksimal yang ditetapkan pada indikator ini, yaitu 40 poin.

b. Kemampuan siswa dalam menceritakan kembali cerpen pada indikator pemyampaian tokoh diperoleh nilai rata-rata 28,63 dari nilai maksimal yang ditetapkan pada indikator ini, yaitu 30 poin.

c. Kemampuan siswa dalam menceritakan kembali cerpen pada indikator pemyampaian latar diperoleh nilai rata-rata 23 dari nilai maksimal yang ditetapkan pada indikator ini, yaitu 30 poin

Setelah proses pembelajaran siklus I dan siklus II dilaksanakan, maka diperoleh hasil evaluasi Evaluasi siswa seperti pada tabel berikut: 
Tabel 3. Perbandingan Hasil Evaluasi Siklus I dan II

\begin{tabular}{|c|c|c|c|c|c|}
\hline \multirow[b]{2}{*}{ No } & \multirow[b]{2}{*}{ Nama Siswa } & \multicolumn{4}{|c|}{ Nilai Akhir } \\
\hline & & Data Awal & Siklus I & Siklus II & Keterangan \\
\hline 1 & Adisty Cantika & 75 & 80 & 80 & Meningkat \\
\hline 2 & Aldy Sahputra & 75 & 75 & 75 & Tetap \\
\hline 3 & Arif Saputra & 70 & 85 & 85 & Meningkat \\
\hline 4 & Aulia & 80 & 80 & 80 & Tetap \\
\hline 5 & Aulia Akbar & 65 & 85 & 85 & Meningkat \\
\hline 6 & Azizah Sausan & 65 & 50 & 85 & Meningkat \\
\hline 7 & Dede Febriani & 65 & 75 & 85 & Meningkat \\
\hline 8 & Diandra & 65 & 75 & 75 & Meningkat \\
\hline 9 & Dimas & 75 & 80 & 85 & Meningkat \\
\hline 10 & Diva Adesyahputri & 80 & 80 & 80 & Tetap \\
\hline 11 & Dani Fauzan & 65 & 85 & 85 & Meningkat \\
\hline 12 & Dyra Salsabila & 65 & 85 & 85 & Meningkat \\
\hline 13 & Emir Abdullah & 90 & 85 & 85 & Menurun \\
\hline 14 & Felix Gibber & 65 & 85 & 85 & Meningkat \\
\hline 15 & Fatani Saputra & 60 & 70 & 80 & Meningkat \\
\hline 16 & Fasy & 80 & 85 & 85 & Meningkat \\
\hline 17 & Fuji Cintia & 80 & 70 & 70 & Menurun \\
\hline 18 & Gatot & 80 & 85 & 85 & Meningkat \\
\hline 19 & Hammed Reza & 65 & 85 & 85 & Meningkat \\
\hline 20 & Ihzaty & 80 & 65 & 80 & Tetap \\
\hline 21 & Veremy Devito & 80 & 80 & 85 & Meningkat \\
\hline 22 & Lidya & 80 & 95 & 95 & Meningkat \\
\hline 23 & Melani Putri & 80 & 85 & 85 & Meningkat \\
\hline 24 & M Fadhil & 60 & 65 & 80 & Meningkat \\
\hline 25 & M Herdy & 65 & 60 & 85 & Meningkat \\
\hline 26 & M Afif & 90 & 70 & 70 & Tetap \\
\hline 27 & M Setya & 65 & 85 & 85 & Tetap \\
\hline 28 & M Fadilah & 60 & 85 & 85 & Meningkat \\
\hline 29 & Nabela & 80 & 65 & 80 & Tetap \\
\hline 30 & Nurdianah & 80 & 80 & 85 & Tetap \\
\hline 31 & Ratna & 80 & 95 & 95 & Meningkat \\
\hline 32 & Revicasya & 65 & 80 & 85 & Tetap \\
\hline 33 & Riza Adila & 80 & 85 & 85 & Tetap \\
\hline 34 & Rizkiu Dwi & 65 & 95 & 80 & Meningkat \\
\hline 35 & Ryan Wilson & 60 & 85 & 85 & Tetap \\
\hline 36 & Sahira & 80 & 80 & 95 & Tetap \\
\hline 37 & Sisca & 70 & 75 & 85 & Meningkat \\
\hline 38 & Tiara Putri & 60 & 85 & 95 & Meningkat \\
\hline 39 & Vinny Dwi & 60 & 65 & 75 & Meningkat \\
\hline 40 & Widya & 55 & 45 & 70 & Meningkat \\
\hline & Jumlah & 2860 & 3125 & 3325 & \\
\hline & Rata-rata & 71.50 & 78.13 & 83.13 & Meningkat \\
\hline & Kategori & & & gkat & \\
\hline
\end{tabular}

Terlihat adanya peningkatan kemampuan menceritakan kembali cerita pendek dengan metode diskusi siswa Kelas IX.4 SMPN 21 Pekanbaru pada Siklus I dan II. Peningkatan terjadi hampir pada seluruh siswa kelas yang menjadi objek penelitian dengan nilai rata-rata penilaian sebesar 83,13

Berdasarkan pada hasil yang diperoleh dari hasil evaluasi siswa, maka penulis hanya melakukan 2 siklus tindakan. Karena sudah jelas hasil yang diperoleh dalam peningkatan kemampuan menceritakan kembali cerpen dengan metode diskusi siswa Kelas IX.4 SMPN 21 Pekanbaru terlihat meningkat lebih baik secara rata-rata sudah melebih $78 \%$.

\section{KESIMPULAN}

Hasil Berdasarkan hasil penelitian, maka diperoleh kesimpulan terhadap penelitian ini adalah untuk meningkatkan kemampuan menceritakan kembali cerita pendek (cerpen) dengan metode diskusi terhadap siswa Kelas IX.4 SMPN 21 Pekanbaru sebagai berikut:

a. Rata-rata siswa pada tes awal dikategorikan sedang dengan nilai rata-rata 71,50 , dengan nilai persentase ketuntasan $40 \%$ atau ada 16 siswa yang dinyatakan tuntas dan sisanya 24 siswa dinyatakan tidak tuntas dengan persentase $60 \%$,

b. Pada siklus I, nilai kemampuan rata-rata siswa naik menjadi 78,13 dengan kategori sedang, dengan nilai persentase ketuntasan $65 \%$ atau dengan jumlah 26 orang siswa,

c. Pada siklus II kemampuan rata-rata siswa telah dikategorikan tinggi dengan nilai rata-rata 88,13 , tetapi dengan ketuntasan $85 \%$, dimana nilai ketuntasan siswa telah tercapi.

Pernyataan di atas menunjukkan bahwa kemampuan menceritakan kembali cerita pendek (cerpen) dengan metode diskusi siswa Kelas IX.4 SMPN 21 Pekanbaru dapat ditingkatkan melalui metode diskusi, dengan demikian hipotesis penelitian yang berbunyi: "Peningkatan Kemampuan 
menceritakan kembali Cerita Pendek (Cerpen) dengan Metode diskusi Siswa Kelas IX.4 SMPN 21 Pekanbaru dapat "diterima"..

a. Untuk meningkatkan kemampuan menceritakan kembali cerpen dengan metode diskusi di sekolah diharapkan kepada Guru Bahasa Indonesia dan Sastra dapat menggunakan Metode diskusi.

b. Untuk siswa agar lebih serius dalam mempelajari tentang kemampuan menceritakan kembali cerita pendek dengan metode diskusi

c. Kepada peneliti selanjutnya agar meneliti lebih dalam tentang kemampuan menceritakan kembali cerita pendek dengan metode diskusi demi kesempurnaan penelitian selanjutnya.

d. Kepada kepala sekolah perlu memamtau dan membina terhadap dampak kegiatan Penelitian Tindakan Kelas (PTK), sebagai bahan penilaian kemajuan yang telah dicapai, sehingga apa yang ditemukan pada PTK dapat diimplementasikan dalam pelaksanaan pembelajaran di sekolah.

e. Kepada pengawas perlu mengadakan kunjungan supervisi terhadap peneliti dalam pelaksanaan PTK sedang berlangsung, agar apa yang ditemukan dapat diimplementasikan pada proses pelaksanaan pembelajaran.

\section{DAFTAR PUSTAKA}

[1] Mustafa dkk. 2006. Berbicara. Pekanbaru: FKIP UNRI.

[2] Mulyasa, 2007, Desain Pembelajaran, Bandung: Rosda Karya

[3] Muhibbin Syah, 1995, Psikologi Belajar, Jakarta: Rineka Cipta

[4] Santosa Puji dkk. 2005. Materi dan Pembelajaran Bahasa Indonesia SD. Jakarta: UT.

[5] Rostiyah, 2001. Strategi Belajar Mengajar, Jakarta: Rineka Cipta

[6] Tarigan Djago dkk. 2001. Pendidikan Keterapilan Berbahasa. Jakarta: Universitas Terbuka.

[7] 1998. Pendidikan Keterapilan Berbicara. Jakarta: Depdikbud.

[8] Tarigan Henry G. 1998. Berbicara Sebagai Suatu Keterampilan Berbahasa. Bandung: Angkasa 